\title{
Career fast-forward
}

\section{An early stab at leadership can help a young scientist to imagine heading a group, argues Katharina Genreith.}

$\mathrm{I}$ am a 26-year-old PhD student. I am also an independent group leader - of a sort. I acquire my own funding, and run a lab with eight team members.

How could such a young student have such a serious responsibility? I am taking part in the Life-Science Lab: an unconventional education initiative at the German Cancer Research Center in Heidelberg. The programme gives students from high-school to PhD level the opportunity to join independent, mixed research groups and work on scientific projects of their choosing - in their own labs.

Students get the chance, in essence, to fastforward their careers and see what it is like to be two steps ahead on the academic ladder. I have been given a glimpse of my future, working as a responsible group leader on synthetic biology.

Apart from our remarkably low mean age, my team and I are just like any bunch of scientists. What we might lack in experience and maturity, we have tried to offset with enthusiasm, hard work and the occasional chocolate cake at lab meetings. Our project uses genetically modified Escherichia coli bacteria to make living ultraviolet-light sensors integrated into jewellery pieces, to alert people when the sun has started to cause damage to their DNA.

\section{COMPETITIVE DRIVE}

Despite our enthusiasm, our productivity had been flagging. It can be difficult to convince volunteer team members to sacrifice their Sundays in the absence of deadlines or external incentives. But productivity got a boost when, with fellow Life-Science Lab participant Dominik Niopek, we joined the International Genetically Engineered Machine competition (iGEM). Suddenly, we had access to thousands of DNA parts (virtual and actual) from iGEM's Registry of Standard Biological Parts, and had the outstanding incentive of measuring ourselves against teams from all over the world. At the same time, however, we were exposed to clear project requirements, deadlines and the small problem of acquiring US $\$ 10,000$ in funding for lab disposables and expenses for travelling to the competition finals in Greenfield, Indiana. I felt the pressure of being in charge.
The work demanded personal sacrifices, caused sleep deprivation and meant that we had to cope with high expectations from the sponsors and ourselves. But it was worth it. Ten weeks after our team signed up for the iGEM competition, we had raised about US $\$ 13,000$ in funding from biotechnology companies, government education funds and generous grandmothers.

The experimental results were better than we had dared to hope. At the iGEM high-school competition jamboree, the judges awarded us not only the main prize - a green BioBrick trophy in the shape of a Lego brick - but also five out of ten special prizes.

\section{JUMPING INTO THE DEEP END}

Changing my perspective - from $\mathrm{PhD}$ student to group leader - gave me the opportunity to develop a scientific project from beginning to end, with responsibility for both the research and my team. I gained practical experience of managing a project, reconciling competencies and team dynamics, assigning tasks and providing constructive feedback. I also saw my shortcomings, including my tendency to grow impatient, which raised anxiety levels.

But most importantly, the career fastforward taught me to come up with my own project ideas rather than relying on the expertise of my supervisor. I discovered that what I really love about science is the creative process and the possibility of making an impact on society. The experience reinforced my desire to pursue a research career.

By becoming group leaders, early-career scientists have a chance to broaden their horizons and acquire skills such as project organization, mentoring and coordination of a research team. And student-led research teams would work well in nearly any branch of science. The only things really required are a genial, enthusiastic group of students, lab space, the courage to stray off the beaten path - and the occasional chocolate cake.

Katharina Genreith is a PhD student in cancer biology at the German Cancer Research Center in Heidelberg, Germany. She worked on the Life-Science Lab initiative.
WOMEN IN SCIENCE

\section{Video competition}

In June, the European Commission released a short video intended to attract women to science careers as part of its Science: It's a Girl Thing campaign (http://science-girl-thing.eu). The widely maligned, sexually suggestive clip - created by an external production company-depicted flirtatious models strutting through a lab setting, ostensibly to help to make cosmetics. Criticized for trivializing the issue, it was soon taken down. Now the European Science Foundation in Strasbourg, France, has launched an online contest asking for members of the public from around the world, including scientists, to submit a video that the European Commission might use in its continuing womenin-science campaign. Entries must be submitted by 19 November and be no more than one minute long; they can be uploaded on either YouTube or Facebook. One prize will go to the video that earns the most votes from viewers between 19 and 28 November, and a jury will select two further winners. Each winning team will receive $€ 1,500$ (US\$1,950).

\section{FACULTY}

\section{Boosting flexibility}

In an effort to retain faculty members by improving their work-life balance, Stanford University School of Medicine in California has created a creditbanking system. Faculty members will receive credits for the time they spend on mentoring, committee work and similar tasks; they can cash in the credits for gift certificates at businesses approved by the medical school to help them with tasks such as editing manuscripts, writing grant applications, housework or meal preparation. The system aims to put a formal value on time spent on non-research activities. Faculty members "can buy back time that they would have spent at home to help them elevate their role in the lab", says Jennifer Raymond, a neurobiologist at Stanford and associate dean for faculty development. "We're hoping to demonstrate that we can increase faculty flexibility and sanity," she adds. "We also believe that we'll increase retention and recruitment." The pilot programme will run for a year, after which administrators will compare faculty productivity and workplace satisfaction before and after the launch. If the pilot programme is deemed to be successful, it will be expanded to faculty members across the university. 